\title{
The Effect of Work Stress, Compensation, and Motivation to Organizational Commitment
}

\author{
FX. Suwarto ${ }^{1}$, Suhartono ${ }^{2}$ \\ \{fx.suwarto@yahoo.com ${ }^{1}$, suhartono@budiluhur.ac.id ${ }^{2}$ \} \\ Magister Management, Budi Luhur University, Jakarta Selatan 12260, Indonesia ${ }^{1}$, Postgraduate \\ Studies, Universitas Budi Luhur, Jakarta Selatan 12260, Indonesia ${ }^{2}$
}

\begin{abstract}
The purposes of the study are to analyze the effect of work stress, compensation, and motivation to organizational commitment and determine the level of work stress, compensation, and employee motivation. The questionnaire data is obtained by 67 respondents. The descriptive statistical analysis is applied to determine the level of work stress, compensation, and motivation. The multiple linear regression analysis is applied to expose and investigate the influence of work stress, compensation, and motivation to organizational commitment whereas test the partial effect is done by t test and influence together done with test $\mathrm{F}$. The research results is shown that the level of work stress, compensation, and motivation are in the moderate level. Moreover, it concluded that job stress, compensation, and motivation influence to organizational commitment together influence $79,8 \%$, the rest equal to $20,2 \%$ is not another variable included in research model. Either managerial implications or organizational commitment is a relatively strong employee identification and involvement of employees to their organization. The conclusion for the company must either build or grow the commitment because with highly committed employee can minimize the costly of employee recruitment as consequently turnover ratio of company employees can be low.
\end{abstract}

Keywords: work stress, compensation, motivation, commitment, organizational.

\section{Introduction}

Tense of industrial competition and economic crisis of today's society are often the issue for the company going decline. The anticipating of decline is required the existence of reliable human resource management [1]; the reason is because the recognizing deeply the human being is one important factor in achieving company goals. Despite in fact, the company does not have competent human resources and subsequently it would be in strivings to advance the competition [2]. All exemplify that the company cannot be separated from the role of human resources by considering their needs.

The employee expectation was expressed in their greatest performances. The companies are not only required of excellent performance but also highly sense of commitment to the employee. Employees commitment is very important for the company because by having a highly committed employee the company could minimize cost in recruitment and could also increase the productivity from the existing employees [3]. Hence, the commitment must be exist and the company should create a organizational commitment [4]. Creating highly committed employee must be compensated by less job stress, compensation, and motivation [5]. Stress is an instinctively response to a situation perceiving as challenging or threatening one's health [6]. 
Stress is experienced by many people without exception and the causes vary such as work, tasks, job goals, and others [7].

According to Chandola (2010) stress is a dynamic condition for exposing the individual to the opportunities, demands, or resources associated with expectation and the uncertain and important result. Some stress can be either positive or some can be negative [8],[9]. Executive remuneration does not only cover the financial remuneration but also the incentive for compensating the stress, i.e: indirect financial payments like insurance and vacations [10]. Also Robbins and Mary Coutler (2007) suggested that to push and to compensate managers cost in recruitment and could also increase the productivity from the existing.

To do a high-level stress in business of achievement the remuneration should cover all the conscquences. Researches revealed that the effect of work stress, compensation, and motivation on organizational commitment were the concerns to employees productivity, particularly for manager with the large number of employees, i.e larger than 200 employees [11],[12].

\subsection{Organizational Commitment}

Robbins, Judge and Hasham, (2009) defines organizational commitment is reflects the feelings of likes or dislikes of employees towards the organization as an attitude [13]. O'Reilly and Chatman (1986) and Saari and Judge ( 2004) mentioned that employees' commitment to the organization as an individual's psychological bond to the organization including work involvement, loyalty and a sense of trust in organizational values [14],[15]. Meyer et al., (2002) suggest that there are three components of organizational commitment: Affective commitment, Continuance commitment, Normative commitment [16].

\subsection{Work Stress}

According to Robbins, Judge and Hasham (2009) stress is a dynamic condition in which an individual is exposed to the opportunities, demands, or resources associated with what the individual desires and whose results are deemed uncertain and important. Some stress can be positive and some can be negative [13].

\subsection{Compensation}

Conyon, (2006) and Dessler (2013) stated that employee compensation covers all forms of payment that are given to employees and arises from their employment relationship. Employee compensation has two main components: direct financial payments (wages, salaries, incentives, commissions, and bonuses) and indirect financial payments (financial allowances such as insurance and vacation paid by employers) [17].

\subsection{Motivation}

In accordance to Robbins, Judge and Hasham (2009) motivation is the mechanism of willingness to do high-level business to accomplish organizational goals, conditioned by the ability of the business to appease the individuals need. 


\subsection{Research Hypothesis}

Robbins et al., (2009) defined stress is a dynamic condition in which an individual is exposed to the opportunities, demands, or resources associated with what the individual desires and whose results are deemed uncertain and important. Research is conducted that job stress has a negative effect on organizational commitment.

H1: Job stress has a significant effect on organizational commitment According to Dessler, (2013) an employee compensation covers all forms of payment that are given to employees and arises from their employment relationship. Research is conducted that compensation is positive for organizational commitment by Sudarwanti Retna ningsih.

H2: Compensation has a significant effect on organizational commitment In accordance with to Robbins et al., (2009) motivation is the process of willingness to do highlevel business to accomplish organizational goals, conditioned by the ability to appease the needs of some individuals. Research is conducted that motivation has a positive effect on organizational commitment by Irawan Ciptodihardjo.

H3: Motivation has significant effect on organizational commitment

Based on the completed research, it can be concluded that job stress has negative effect on organizational commitment, while compensation and motivation have positive effect on organizational commitment.

H4: Job Stress, Compensation, and Motivation have a significant effect on Organizational Commit

\section{Methodology}

The study population was 200 people. The applying of Slovin's formula can be used in the questionnaire is 67 people as the samples. The Primary data collecting method is obtained directly from respondents in filling questionnaire closed form. Likert Likert scale is used to give the answer score in the questionnaire with 5 points with intervals ranging from Strongly Disagree (SD) to Strongly Agree (SA).

\subsection{Hypothesis Test}

The Multiple linear regression analysis is used to perceive the influence of independent variable to dependent variable. The independent research variable are: work stress (X1), compensation (X2), and motivation (X3). These will influence the dependent variable with the organizational commitment $(\mathrm{Y})$.

a. Simultaneous Significance Test (Test Statistic F)

The $\mathrm{F}$ test is an assessment of all independent variables included in the model of joint influence on the dependent variable.

b. Determination Coefficient Analysis

The determination coefficient value is between the value of zero and the value of one. The small value of $\mathrm{R}^{2}$ means that the ability of the independent variables (work stress, compensation, and motivation) in defining the dependent variable (organizational commitment) has limitations.

c. Partial Significance Test ( $\mathrm{t}$ test) 
The $\mathrm{T}$ test is applied to determine the influence of each independent variable to the dependent variable with the formulation of the null hypothesis (Ho) and the alternative hypothesis (Ha).

\section{Result And Discussion}

The research data analysis is completed by using multiple linear regression analysis to know the influence of independent variable to dependent variable. The research has independent variable that is: work stress (X1), compensation (X2), and motivation (X3) which will influence the dependent variable that is organizational commitment $(\mathrm{Y})$.

Based on the summary of regression test results, the regression equation of the results of this study can be written as follows.

$\mathrm{Y}=1.424-0.167 \mathrm{X} 1+0.346 \mathrm{X} 2+0.262 \mathrm{X} 3+\mathrm{e}$

The regression equation above can be interpreted constant value of 1.424 , this value is constant value of organizational commitment if $(X 1, X 2, X 3=0)$ or organizational commitment value before influenced by independent variable equal to 1,424 . The regression coefficient of work stress variable (X1) is -0.167 , it means that every $1 \%$ increase of employee work stress will decrease organizational commitment sebsar 0,167 and vice versa if job stress decrease $1 \%$ hence will increase organizational commitment equal to 0,167 .

The regression coefficient of compensation variable (X2) is 0,346 , it means that every $1 \%$ increase of commitment will increase organizational commitment equal to 0,346 . If compensation decrease $1 \%$, it will decrease organizational commitment equal to 0,346 . The regression coefficient of motivation variable (X3) is 0,262 , it means that every $1 \%$ improvement of motivation will increase organizational commitment equal to 0,262 . If motivation decrease $1 \%$ it will decrease organizational commitment equal to 0,262 .

The amount of influence of work stress, compensation, and motivation to organizational commitment of 0.798 or 79.8 while the rest of $20.2 \%$ is explained by other variables outside the model under study.

\subsection{Hypothesis Testing 1: Job Stress Has a Significant Effect on Organizational Commitment}

The working stress hypothesis test has negative effect to organizational commitment analyzed by using partial significance test ( $\mathrm{t}$ test). Ho is rejected and Ha accepted Based on significance level $t_{\text {account }}(-2,443)$ and significance $\alpha 0,017<0,05$. The implication work stress have negative and significant influence on organizational commitment thus the first hypothesis of this study can be proven. Job stress variable has negative and significant influence to organizational commitment equal to $16,7 \%$.

\subsection{Hypothesis 2: Compensation Has a Significant Effect on Organizational Commitment}

The compensation hypothesis test has positive effect to organizational commitment analyzed by using partial significance test ( $\mathrm{t}$ test). Ho refused and Ha accepted based on can be seen that significance $t_{\text {account }}(4,707)$ and significance $\alpha 0,000<0,05$. The interpretation is compensation have positive effect and significant to organizational commitment thus the second hypothesis in 
this study can be proven. The compensation variable has a positive and significant influence on organizational commitment of $34.6 \%$.

\subsection{Hypothesis 3: Motivation Has a Significant Effect on Organizational Commitment}

The motivation hypothesis test has positive effect to organizational commitment and it is analyzed by using partial significance test ( $\mathrm{t}$ test). Ho refused and $\mathrm{Ha}$ accepted Based on can be seen that significance $t_{\text {account }}(4,098)$ and significance $\alpha 0,000<0,05$. The interpretation is motivation have positive effect and significant to organizational commitment so the third hypothesis in this study can be proven. Motivation variable has positive and significant influence to organizational commitment equal to $26,2 \%$.

\subsection{Hypothesis 4: Job Stress, Compensation, and Motivation Have a Significant Effect on Organizational Commitment}

The test of hypothesis 4 is conducted by simultaneous test ( $\mathrm{F}$ test) to expose the independent variables (work stress, compensation and motivation) significantly influence the dependent variable of organizational commitment. Ho is rejected and Ha accepted based on the analysis results obtained $F_{\text {account }} 87,911$ and significance $\alpha(0,000<0.05)$, the interpretation means that the three independent variables work stress, compensation and motivation have a significant influence on the variable organizational commitment, thus the fourth hypothesis of this study can be proven. The amount of influence of work stress, compensation, and motivation to organizational commitment of 0.798 or as much as $79.8 \%$.

\section{Conclusions}

Based on the result of arithmetic mean analysis, it can be identified that employee job stress on UD production field. Bintang Walet Klaten is in low category, it can be seen from the analysis of mean value on each indicator. The low workload shows that the employees of the production area feel the workload is not excessive with the mean workload value of 2.38 (low). The results can be seen from the description of respondents that most respondents stated that they still have enough time to complete each - his job and respondents stated that the job performance standards they are doing now are not too high. The mean work conflict value is 2.45 (low). The low value do not have conflict in the work environment and this conflict usually occurs when employees compete against demands. The mean ambiguous value is 3.44 (high). This interpretation means the respondents recognize the goals and objectives of the current job and they also know exactly what the expectation from the current job as well as knowing what has become their responsibility for their work. The comprehensible mean stress value of employee employment field is in the category of being moderate.

The exposing results of the mean value analysis on financial compensation is 2.48 (low) that means the responders consider the financial compensation they receive is currently in the low category. The employee is not contented with the current monthly salary. It received according to employees are not only in accordance with the overtime given by the company but also the bonus given by the company also has not satisfied the employee.

Non-financial compensation is a compensation in the form of financial benefits such as insurance and leisure, build upon the analysis of the mean non-financial compensation obtained 
by the mean value of 3.12 (moderate), the result is to provide nonfinancial compensation to the employees fairly well.

The next hypothesis testing is positive and significant impact motivation on organizational commitment. Based on the mean value analysis on physiological needs of 2.65 (moderate), it has a meaning of the production field employees have motivation on physiological needs quite well. These results indicate that employees consider that the salary received by current employees is sufficient to meet basic needs and bonuses are also given in accordance with the agreement. The necessity of security is obtained a mean value of 2.78 (moderate). The essential security is the safety and protection of physical and emotional disturbances as well as the certainty of physical needs will continue to be met. The result is shown that the security of employees' prosperity. The security guarantees have been provided for providing the health insurance to employees, and giving more attention to the safety of work employees by the company.

The social necessity is a need of closeness with being part of the group. It is managed by co-workers and the result of the mean analysis is 3.40 (moderate). The results indicate that production's employee's field can cooperate enough with their coworkers. They also have the opportunities to participate in group / team work. Moreover, they are established a harmonious atmosphere among colleagues in the work environment.

Self-esteem needs a mean value is 3.09 (moderate), it means that internal self-esteem factors, such as self-esteem, autonomy, and achievement and external self-esteem factors such as status, recognition, attention have been obtained by employees in the field of production are shown by the award for employees in accordance with employee achievement, the employer gives an opportunity to the employee in leading the working group / work team and open / receive ideas from fellow employees The self-actualization necessity is gained by a mean value of 2.88 (moderate), it means the growth and achievement of potential employees, and selffulfillment, the encouragement to become what employees are able to achieve enough fulfilled. The company has provided an opportunity for employees to increase their potential, provide opportunities in self-fulfillment for self-improvement and support the opportunities for employees to increase rank within the company. The comprehensive of production employees' motivation is in the category of well enough.

The result of mean value analysis on affective commitment is 2.60 (low), it means that the production department employees do not have the desire to be part of the company it can be caused the employees do not have closeness with the company. The mean value is 2.64 (moderate) on a sustainability commitment, it means that employees in the production department will continue to work, because they still need salary and other benefits for their viability and no other job as replacements, so the category sustainability commitment is enough.

The mean value is 2,88 (moderate) in normative commitment, it means that employees have their own values because of the consciousness of commitment to the company is the obligation by an employee. The comprehensive commitment variables are categorized as moderate category; it means the production officer has sufficient commitment to the company to survive as an employee of the company.

\subsection{Managerial Implications}

The organizational commitment is a relatively strong employee identification and involvement that employees must have for their organization. Commitment is very important for the company. High commitment in the company can reduce the costly for the recruitment of new employees to reestablish the senior and retired employees. The research result of the employee's 
commitment to the company is comprehended as the moderate category, therefore it is necessary to support the management especially the HRD in managing the employees to be awareness of work stress, compensation and motivation. It is because the significant three variables to Organizational Commitment.

\section{References}

[1]T. A. Kochan and J. Chalykoff, "Human resource management and business life cycles: some preliminary propositions," 1985.

[2]R. Jassim and G. Jaber, "Competitive advantage through the employees,” Res. Pap. Univ. Auckl. ..., pp. 387-413, 1998.

[3]N. Bloom, "Human Resource Management and Productivity," Handb. Labor Econ., no. 54, pp. 1697-1767, 2010.

[4]D. V. Dixit and M. M. Bhati, "A Study about Employee Commitment and its impact on Sustained Productivity in Indian Auto-Component Industry,” Eur. J. Bus. Soc. Sci. Vol., vol. 1, no. 6, pp. 34-51, 2012.

[5]Y. Hamdan, "Work Stress and its Management : A Practical Case Study," Eur. J. Bus. Manag., vol. 4, no. 18 , pp. 33-37, 2012.

[6]Latha Krishnan, "Factors Causing Stress among Working Women and Strategies to Cope Up," IOSR J. Bus. Manag., vol. 16, no. 5, pp. 12-17, 2014.

[7]P. Landsbergis, "Unhealthy Work: Causes, Consequences, Cures," Unhealthy Work Causes, Consequences, Cures, no. February, pp. 193-209, 2009.

[8]T. Chandola, Stress at work. 2010.

[9]R. Jahanian, S. M. Tabatabaei, and B. Behdad, "Stress Management in the Workplace," Int. J. Acad. Res. Econ. Manag. Sci., vol. 1, no. 6, pp. 1-9, 2012.

[10]M. Conyon, "Executive compensation, taxes, and incentives," Acad. Manag. Perspecitives, pp. 179-201, 2006.

[11]R. Djebarni, "The impact of stress in site management effectiveness.," Constr. Manag. Econ., vol. 14, no. 4, pp. 281-293, 1996.

[12]G. D. Sherman et al., "Leadership is associated with lower levels of stress," Proc. Natl. Acad. Sci., vol. 109, no. 44, pp. 17903-17907, 2012.

[13]S. T. Robbins, T. a Judge, and E. S. Hasham, Organizational Behavior. 2009.

[14]C. O'Reilly and J. Chatman, "Organizational Commitment and Psychological Attachment. The Effects of Compliance, Identification, and Internalization on Prosocial Behavior,” J. Appl. Psychol., vol. 71, no. 3, pp. 492-499, 1986.

[15]L. M. Saari and T. A. Judge, "Employee attitudes and job satisfaction," Hum. Resour. Manage., vol. 43, no. 4, pp. 395-407, 2004.

[16]J. P. Meyer, D. J. Stanley, L. Herscovitch, and L. Topolnytsky, "Affective, continuance, and normative commitment to the organization: A meta-analysis of antecedents, correlates, and consequences," in Journal of Vocational Behavior, vol. 61, no. 1, 2002, pp. 20-52.

[17]G. Dessler, Resource Management Thirteenth Edition. 2013. 